\title{
Development and Evaluation of Web GIS Application for Groundwater Management of Karanganyar Regency
}

\author{
Jumadi, Yuli Priyana \\ Faculty of Geography, Universitas Muhammadiyah Surakarta \\ Corresponding E-mail: Jumadi_geo@ums.ac.id
}

\begin{abstract}
This research aims to develop and evaluate a geospatial application for groundwater resource management at Karanganyar Regency. The system development methodology from Whitten and Bentley (2007) was used in this research. To initiate the project, we discussed with the stakeholders from Karanganyar Regency which came from various related agencies followed by a focus group discussion (FGD) to analyse the system. Computational design and experiment were conducted to design the system prototype. Finally, we implement the system in the Regency. The result shows that the system is complex not only due to the managerial procedures but also the number of involved users (stakeholder) in the system. To address the emerged requirements from the FGD, we propose and develop a web-based GIS application with current open source technology and Google Map API which can be used for collaboration among stakeholders as well as for supporting the decision support purpose in the groundwater management. Currently, Air-tanah, the prototype of the application is available at http://geografi.ums.ac.id/airtanah/. Both quantitative and qualitative evaluation of the system resulted good responses from the users.
\end{abstract}

Keywords: groundwater management, Web-GIS, collaboration

\begin{abstract}
Penelitian ini bertujuan untuk mengembangkan dan mengevaluasi aplikasi geospasial untuk pengelolaan sumber daya airtanah di Kabupaten Karanganyar. Metode yang digunakan adalah metodologi pengembangan sistem dari Whitten dan Bentley (2007). Diskusi dengan para pemangku kepentingan (stakeholder) dari Kabupaten Karanganyar dari berbagai instansi terkait untuk inisiasi pengembangan sistem diikuti dengan diskusi kelompok terfokus (FGD) untuk menganalisis sistem. Desain komputasi dan eksperimen dilakukan untuk merancang purwarupa sistem dilanjutkan dengan implementasi sistem melibatkan stakeholder terkait. Hasilnya menunjukkan bahwa stakeholder membutuhkan sistem yang kompleks tidak hanya karena prosedur manajerial tetapi juga jumlah pengguna yang terlibat dalam sistem. Untuk mengatasi kebutuhan muncul dari FGD, kami mengusulkan dan mengembangkan aplikasi GIS berbasis web dengan teknologi open source mutakhir dan Google Map API yang dapat digunakan untuk kolaborasi antar stakeholder serta untuk mendukung pengambilan keputusan dalam pengelolaan airtanah. Saat ini, prototipe aplikasi yang diberi nama Air-tanah tersedia di http://geografi.ums. ac.id/air-tanah/. Hasil evaluasi kuantitatif maupun kualitatif terhadap aplikasi ini menghasilkan penilaian positif dari para pengguna yang dilibatkan.
\end{abstract}

Kata kunci: pengelolaan airtanah, Web-SIG, kolaborasi

\section{Introduction}

Ground water is an important natural resource for human life. The exploitation to this resource is massively increased along with the growth of population (Santosa dan Adji, 2007; Sudarmadji, 2006). Therefore, management and conservation effort to convince the sustainability of this resource is very crucial. One of the efforts to sustain the existence of groundwater is to conduct balance management between exploitation and potential recharge in which this effort need adequate information of the physical condition of the environment and socioeconomic condition of the surrounding population. Physical condition is strongly 
correlated with the existence of groundwater while population characteristic is related to the exploitation potential.

Physical conditions that the existence of groundwater relay on it are precipitation, geological condition, geomorphology, geohydrology, groundwater basin, and land cover/landuse characteristic. Generally, such environmental components are relatively constant (Jumadi dan Widiyadi, 2009). On the contrary, human factors are dynamic along with the growth of population and human activities. For instance, over exploitation due to the number of population is increased. Another example, improper human activities in recharge area is very harmful to the groundwater condition.

One attempt to control over exploitation is by providing databases which consistently record groundwater exploration administratively. The database is linked to the regional conditions that include physical components mentioned above as basic data in any decisionmaking. Therefore, it is necessary to have an information system based regional (spatial) or commonly known as Geographic Information System (GIS) to accommodate and support this need.

Conceptually, GIS can be integrated with Decision Support System (DSS) or widely called as Spatial Decision Support System (Sugumaran dan DeGroote, 2010). SDSS can be modified and customized to fit with the requirement of users, so that it enables the unskilled user to use GIS in their decision making activities (Jumadi et al., 2012; Jankowski et al., 1997). Moreover, current technology allow collaboration among agencies in making decision or management through web-based application (Carver et al., 2000; Ray, 2007; Rinner, 2003; Sugumaran and DeGroote, 2010; Sugumaran and Sugumaran, 2007) or distributed services (Li et al., 2010; Ostländer, 2004; Sugumaran and DeGroote, 2010). Therefore, we develop a web-based GIS to support groundwater management in Karanganyar Regency. To convince the usability of the system, we conducted evaluation quantitatively and qualitatively with the users. Technologically, this application difference with similar application proposed by Jumadi dan Widiyadi (2009) for groundwater management in Banyumas Regency.

\section{Research Method}

\section{Study Area}

Karanganyar is one of Central Java provinces which is astronomically located at coordinates $110^{\circ} 43^{\prime} 38$ “ $-110^{\circ} 11^{\prime} 24$ ” East longitude and 7 6’17 “-7 46’07” South Latitude. The area is geographically located on the western slopes of Mount Lawu. The overall area is 77.3378,64 ha, with an average altitude of $511 \mathrm{~m}$ above sea level with a variation between 105-2000 meters above sea level (Figure 1). Because of the elevation and the topographical condition, Karanganyar becomes an important area for groundwater recharge for the surrounding cities. 


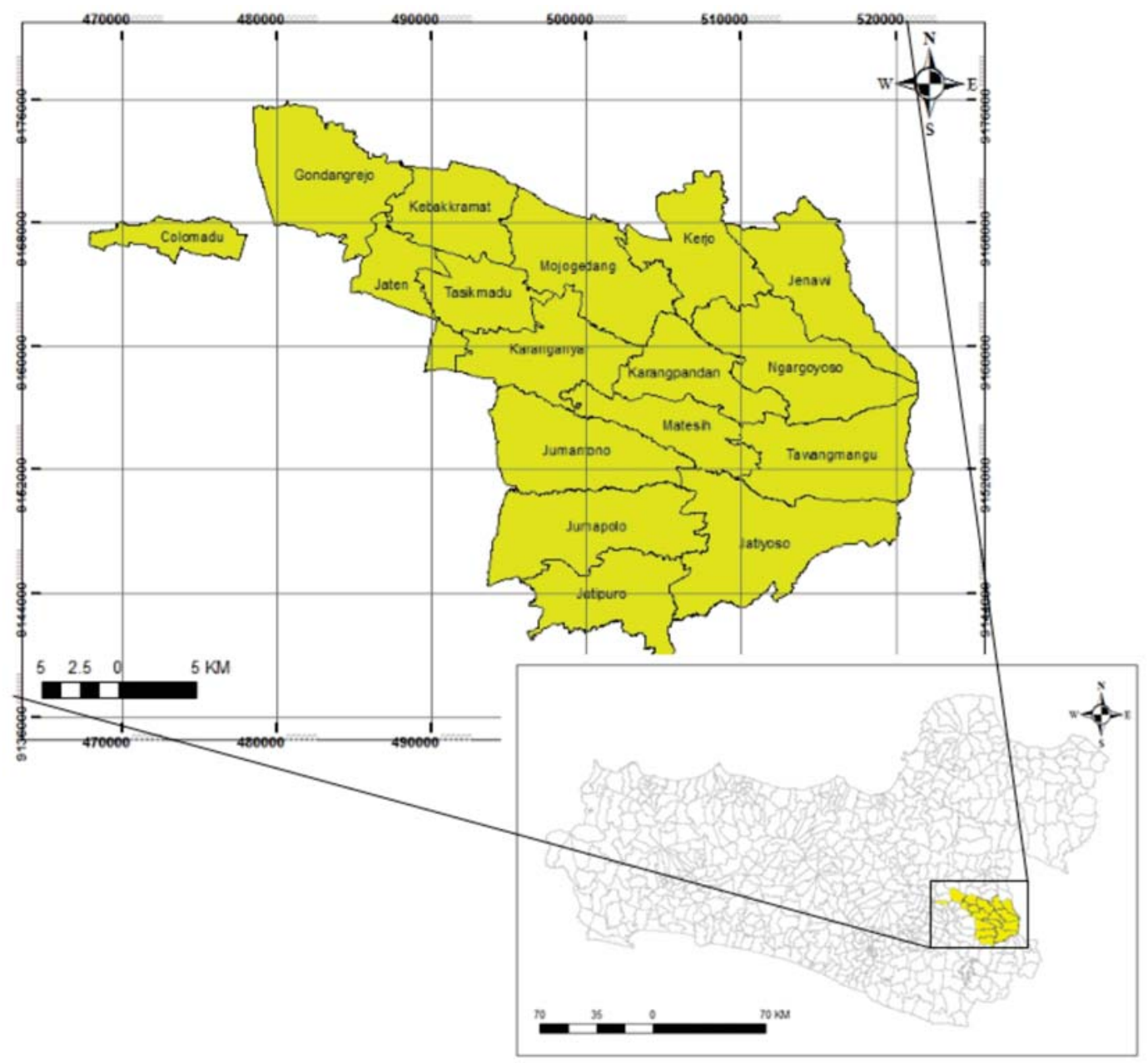

Fig 1. Location of Study

\section{Research Procedure}

Stages of the application development in this study refer to the system development model from Whitten and Bentley (2007): 1) initiation of the system, 2) analysis of the system, 3) system design, 4) implementation of the system (Figure 2). 


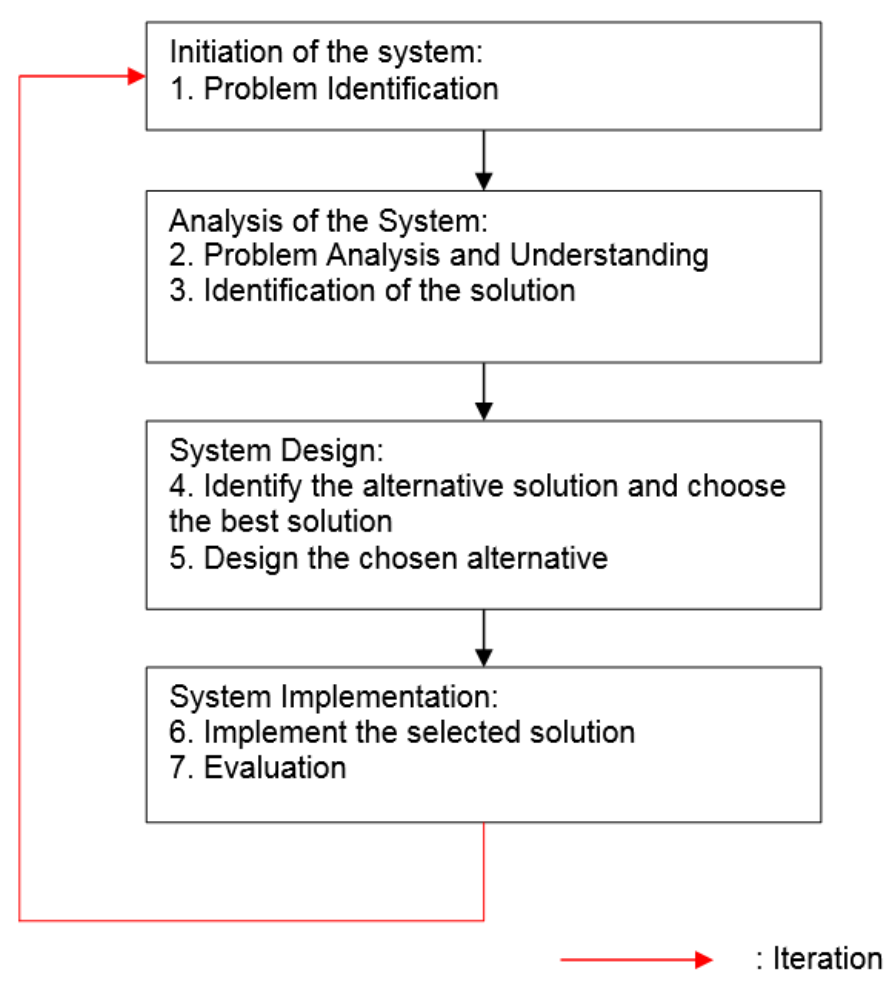

Source: Modified from Whitten and Bentley (2007)

Fig 2. System Development Procedure

\section{Database Design and Development}

We conduct several step to identify the required data: (1) identify themes and data, (2) data collection, (3) collation and entry of data into a Geographic Information System, (3) development of a data group and workspace categorisation. Development of spatial database in this study follows the steps from Nyerges (2011: (1) Conceptual design of database model, a product from this step helps analysts and stakeholders to implement the discussion about the required data and information. In this stage, both groups want to get it "right" as early as possible in the project. (2) Logical design, data processing was done on spatial, attribute, and data types tentatively. The project team, individually or collectively, obtain information (data) to fulfill the requirement from step 1. (3) Physical design, specify the data fields, the valid values, and ranges for all domains, including the feature code domains, primary keys, and types of indexes.

\section{System Procedure Development}

Generally, the developed system is expected to be implemented in the business process of managing the use of groundwater that consists of several procedures: 1) monitoring well locations; 2) the initial information about condition of the location of the planned wells related to geological conditions, geohydrology, rainfall, geomorphology, groundwater basins, the potential for groundwater and groundwater conservation area; 3) data inventory of geological layer; 4 recommendation and licensing of groundwater exploration; 5) monitoring of the quantity and quality of groundwater; 6) monitoring and controlling the use of groundwater; 7) administrative reporting and utilization of groundwater; 8) modelling the spatial location of the wells; 9) modelling of rock layering and well construction; and 10) the modelling of groundwater level fluctuation. A literature study, observation, focus group discussions among stakeholders were conducted to develop the procedures. 


\section{Evaluation}

The evaluation was carried out in two stages. The first phase is the evaluation of the performance and accessibility of the system. At this stage, respondents of users who are already accustomed to using GIS software and users who are not familiar with GIS are involved to quantitatively evaluate the system. The purpose of this evaluation is to provide assurance that the system will be easy to be used by the user either already skilled with GIS (Group 1) or non-skilled (Group 2). After using the application, both groups of users was asked to fill the online questionnaire in this link: https://goo.gl/zlAFIv.

The second stage of evaluation is the evaluation of the feasibility of a system that has been developed with the needs of users (stakeholders). The purpose of this evaluation is to ensure that the system complies with the requirements of stakeholders to support groundwater management process. For this purpose, the applications have installed in the online server that can be accessed using the internet at http://geografi.ums.ac.id/air-tanah/. This evaluation consist of: (1) manual book writing, (2) socialization of the system that has been created, (3) testing of the system, which involves the user, (4) evaluation of the system together with the user.

\section{Result and Discussion}

\section{Analysis of System Procedure}

Formulation of groundwater management system procedures was carried out by conducting focus group discussion (FGD) together with the stakeholders that involved in the management of groundwater in Karanganyar. The meeting was held on July 19, 2014, which was attended by researchers and representatives of Planning, and Department of Public Works (PU) for Energy and Mineral Resources (ESDM).

The discussion started with the user's roles and the procedures of the system. Conceptually, each user has access rights by their authority. The system uses multiple base map stored in the database (RDBMS) as a basis for supporting management procedures of groundwater. The data, with referring to the prospective user location data and location of the planned wells, are used to provide a decision whether or not issued permits to conduct groundwater exploration. The system will ask the coordinate of planned well location when user applying for new exploration permit

The coordinates will be used by the system to perform spatial queries (spatial query) refers to the analysis of the intersection on the spatial database to obtain information on the physical condition of the environment in which the well will be made. Based on the physical condition refer to the database; which are geological information, geohydrology, rainfall, geomorphology, groundwater basins; the decision is made.

If the drilling has been done, the system will ask for information about the layering of rocks that exist at the drilling site. This information will then be used to issue a recommendation construction, including construction drawings are created automatically by the application. To issue recommendations relating to the use of wells and discharge types of utilization that safe to the environment, it is necessary to conduct pumping test to determine the quantity of groundwater and laboratory testing to determine the quality of groundwater. Sequentially and more completely, we formulate procedure of exploration permit of groundwater as follows:

1. Potential users of groundwater (public users) make application of groundwater exploration (drilling).

2. Officers of PU check the physical condition of locations to be drilled about the geological information, geohydrology, rainfall, geomorphology, groundwater basins, and groundwater potential.

3. Based on this information, if according to the conservation map of groundwater, the locations are permitted, the user will perform analysis to make technical 
recommendations of groundwater drilling and issuing drilling permits. Otherwise, if the site does not allow drilling to be done (for examples: recharge area or groundwater conservation area), the system will cancel the request to drill groundwater.

4. If the drilling has been carried out, the officer will ask for information about the layering of rocks. This information will then be used to issue a recommendation construction, including construction drawings.

5. Furthermore, the pump test (pumping test) to determine the quantity of groundwater and laboratory testing to determine the quality of groundwater.

6. Once the data is obtained, the next procedure is a field check to verify the data and retrieval of documentation for the issuance of Permit Use of Water (SIPA) by the local government.

7. SIPA issued to a particular period, therefore, during the time, utilization monitoring of the wells need to be done periodically, including controlling when encountered discrepancy between SIPA with the actual utilization.

8. Data from this survey is then used as the basis for decisions about the sustainability of the use of wells. All decisions oriented to optimize the utilization and conservation of groundwater.

Based on these explanations can be analysed roles (actors) in the management of groundwater in Karanganyar as follows:

Table 1. Actors and the Roles in the Groundwater Management in Karanganyar

\begin{tabular}{|c|c|c|}
\hline No & Actors & Roles \\
\hline 1. & Administrator & System and database management. \\
\hline 2. & Users/people & $\begin{array}{l}\text { Applying for a groundwater exploration permits, applying for } \\
\text { an extension of the exploration permit groundwater, asking the } \\
\text { information suitability of well plan locations with consideration of } \\
\text { the existence of nearby wells. }\end{array}$ \\
\hline 3. & BAPPEDA & $\begin{array}{l}\text { Monitoring utilization of groundwater and groundwater exploration } \\
\text { distribution per area, recommends the termination of licenses, } \\
\text { ensuring the deference rules of the conservation area and the } \\
\text { production area. }\end{array}$ \\
\hline 4. & PU (ESDM) & $\begin{array}{l}\text { Monitor groundwater use permits, issuing permits utilization of } \\
\text { ground water, utilization monitoring, reporting. }\end{array}$ \\
\hline 5. & Local Government & Issuing the permit \\
\hline 6. & DIPENDA & Tax calculation. \\
\hline
\end{tabular}

\section{Spatial Data Model}

Based on the above analysis, the required data was inventoried. The data used in the system needs to be created in the form of spatial data and non-spatial (textual). Spatial databases can be grouped thematically namely general data, physical data areas, data on groundwater, data on the use of groundwater. Meanwhile, the non-spatial database also consists of primary data and secondary data. The primary data obtained through surveys and data collection, and registration while secondary data sourced from the archives and documentation of groundwater management activities.

\section{Web GIS Application Design}

The interface design of the main page includes the representation of spatial and non-spatial, menus, and navigation tools and geographic analysis. Some functions of the application using the model to support decision-making in the management of groundwater and thematic visualization for the appearance of the data (Figure 4). 


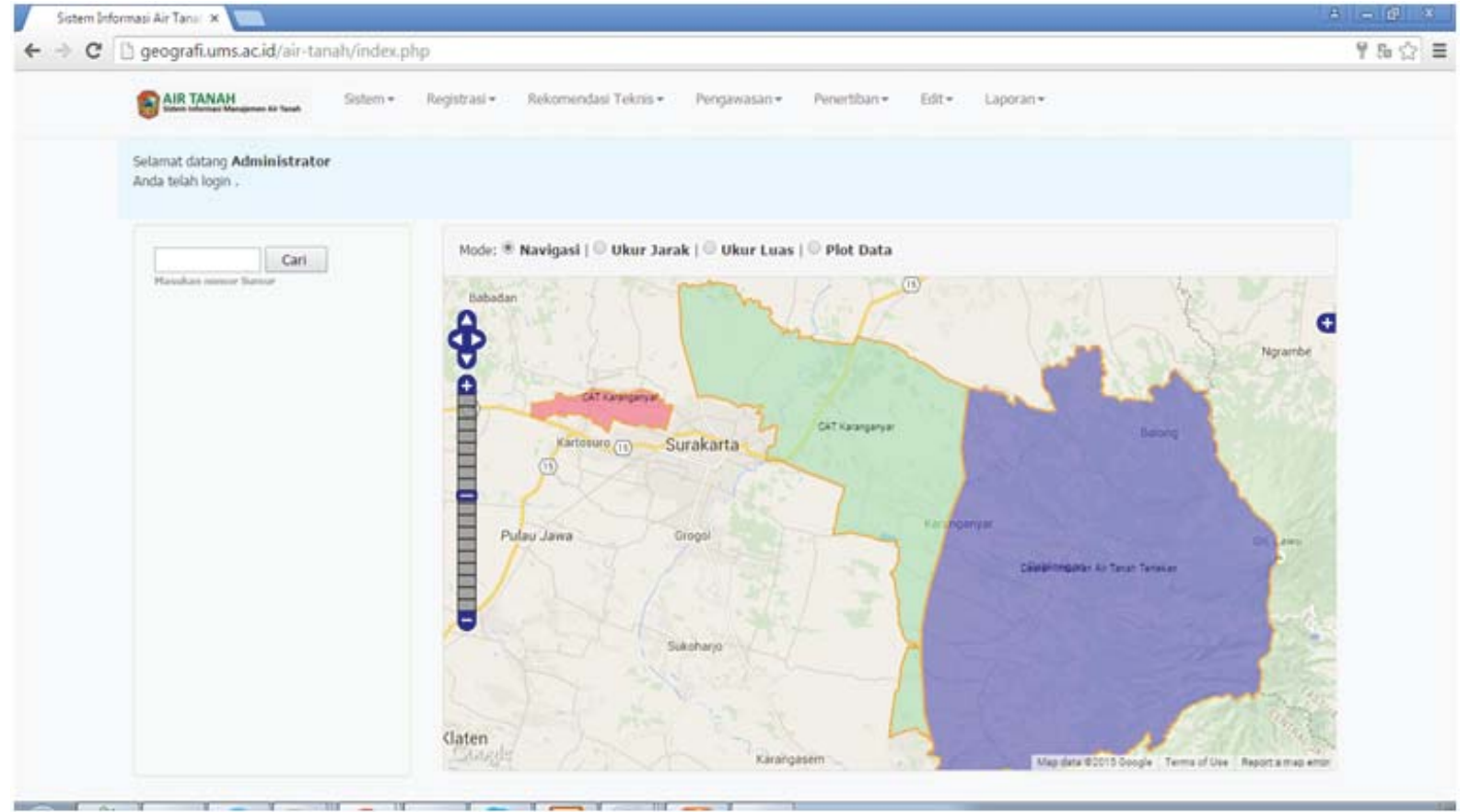

Fig 4. An Examples of Thematic Map

\section{Evaluation}

The quantitative evaluation of five elements results in the following figure. Based on the quantitative evaluation, both GIS-skilled group and unskilled group give almost the same rating for all aspects. This is can be concluded that the application can be easily used by inexperienced users because they able using the application when conducting the test. Based on the test, it can be assured that the implementation of the application that might involve non GIS-skilled users will be successful.

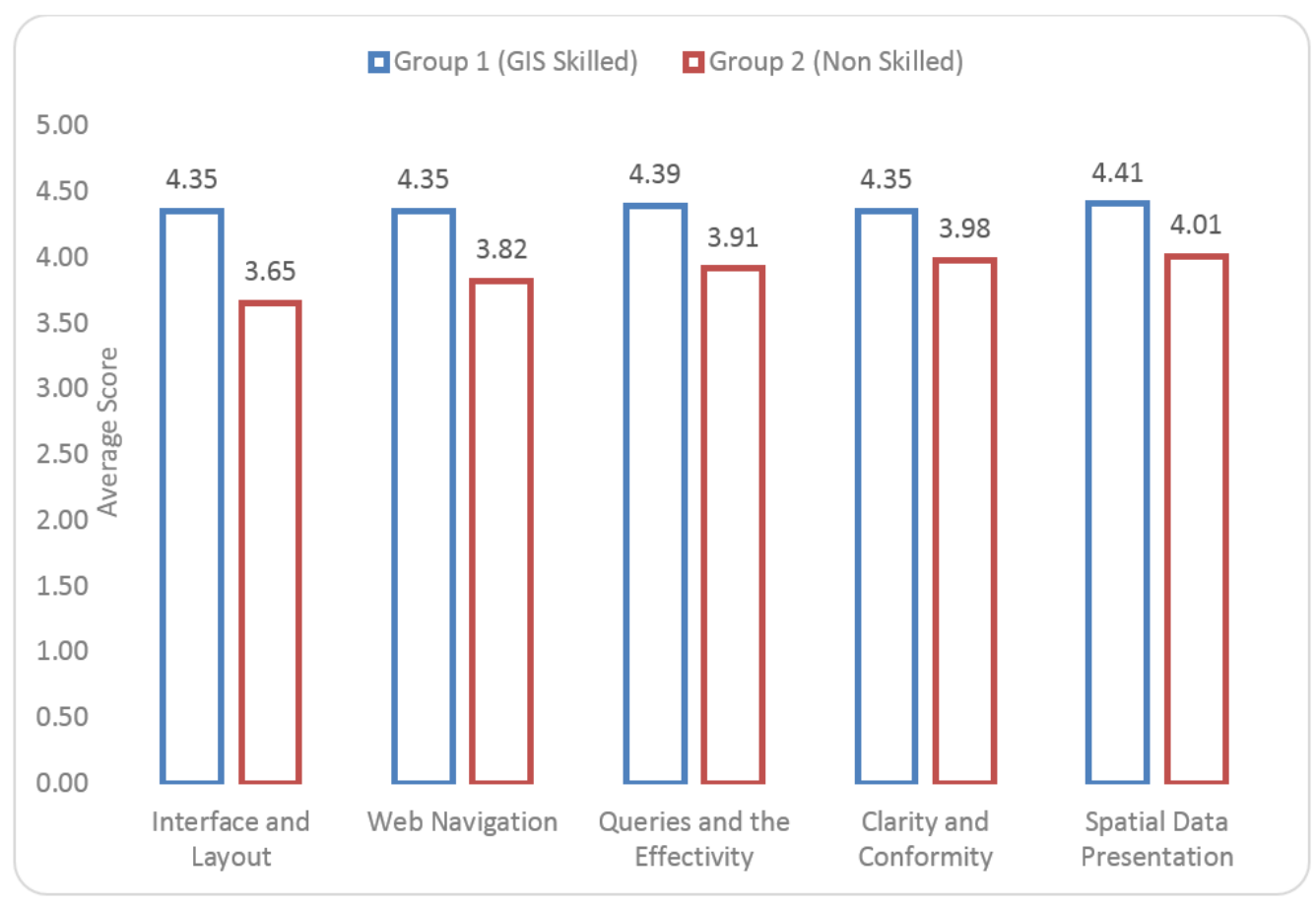

Fig 5. Quantitative Evaluation Result

The second evaluation is a qualitative evaluation. This evaluation is done by conducting 
focus group discussions between researchers and stakeholders consisting of the ESDM, BAPPEDA, and BLH of Karanganyar. The discussion focused on the topic of conformity procedures designed, compliance rules are used, the ability to support decision-making, implementation prospects, and development is needed. Based on the FGD found some evaluative points for future development and direction of the implementation of this application: (1) the procedure is appropriate, but still need some simplification; (2) it is necessary for the development of collaborative decision-making with provincial level; (3) required further coordination with the related agencies to implement the system; (4)necessary to develop the technical implementation procedures in order to facilitate all involved agencies in the business processes.

\section{Discussion}

The usage of GIS in this study, combined with the decision-making system refer to the criteria presented by Sugumaran and Degroote (2010) on Spatial Decision Support System (SDSS). GIS in this case, has also been adapted to the needs of users to facilitate GISunskilled users as recommendations presented by Jumadi et al. (2012) and Jankowski et al. (1997). This is reflected in the high ratings from users of non-skilled user groups at each evaluation point. Web technologies developed are also able to provide multi-agency services that enable collaboration across agencies (Carver et al., 2000; Ray, 2007; Rinner, 2003; Sugumaran and Degroote 2010; Sugumaran and Sugumaran, 2007).

This study has good progress compared with previous studies in the aspects of technology that are reflected in systems architecture and the system evaluation method. Based on the architecture of the system, the system developed in this study shows the progress adapted from the advanced technology. Compared with the previous architecture developed (Jumadi and
Widiadi 2009) the architecture of the system theoretically has better performance and accessibility assessed from several aspects. First, by relying on Javascript framework, Karanganyar groundwater system will be more independent because it does not depend on third-party applications as Banyumas groundwater information systems that rely on the Java Runtime Environment to run the application. Second, the use of OpenLayers framework judged more conform to the standards of the Open Geospatial Consortium (OGC) as an institutional guarantor of spatial data quality standards, thus enabling better data sharing. Third, the use of Google Maps API as a provider of spatial data assessed is reliable and has a good level of data update. The independent data usage such as groundwater information systems Banyumas (Jumadi and Widiadi, 2009) it may be easier in the editing of the data but need more funds and time to provide an update in real-time. Thus, the use of data in the system is considered better.

Based on the aspect of evaluation, this study assessed more comprehensive assessment aspect because it combines quantitative and qualitative aspects. Quantitative aspects based on an evaluation conducted by online questionnaires, while the qualitative aspect is based on the evaluation of the FGD. Evaluation elements used in this assessment is more comprehensive compared with previous studies (Jumadi and Widiadi 2009; Jumadi et al., 2012) that used non-detail evaluation.

\section{Conclusion}

Based on this study it can be concluded that groundwater is the domain of affairs involving multiple stakeholders that need collaborative works of several agencies. Therefore, the synergic workflow of agencies and a system need to be developed to accommodate these conditions. Based on the evaluation, the system developed in this study has met this requirement. Moreover, this research has made 
significant progress when viewed regarding with the used technology and evaluation instruments. Based on the findings of final FGD together stakeholders showed good prospects for implementation. However, some simplifications are needed as required by the discussion forum.

\section{Acknowledgement}

The paper is part of a study conducted using competitive grants from DP2M DIKTI from 2014 to 2015. The author would like to thank DP2M DIKTI that has provided funding.

\section{References}

Carver, S., Evans, A., Kingston, R., Turton, I., 2000. Accessing Geographical Information Systems over the World Wide Web: Improving public participation in environmental decision-making. Inf. Infrastruct. Policy 6, 157-170.

Departemen Energi dan Sumber Daya Mineral. 2004. Kumpulan Teknis Pengelolaan Air Tanah. Jakarta.

Jankowski, P., Nyerges, T.L., Smith, A., Moore, T.J., Horvath, E., 1997. Spatial group choice: a SDSS tool for collaborative spatial decisionmaking. Int. J. Geogr. Inf. Sci. 11, 577-602. doi:10.1080/136588197242202

Jumadi and Widiadi, S. 2009. Pengembangan Aplikasi Sistem Informasi Geografis (SIG) Berbasis Web Untuk Manajemen Pemanfaatan Air Tanah Menggunakan PHP, Java Dan MySql Spatial (Studi Kasus di Kabupaten Banyumas). Forum Geografi. Vol 23 (2) Desember 2009: 123-138.

Jumadi, J., Suharyadi, R., Tuladhar, A.M., 2012. Web-Based Spatial Information System To Support Collaborative Lahars Disaster Management. Indones. J. Geogr. 44.

Li, X., Di, L., Han, W., Zhao, P., Dadi, U., 2010. Sharing geoscience algorithms in a Web service-oriented environment (GRASS GIS example). Comput. Geosci. 36, 1060-1068.

Nyerges (2011). Developing a Geodatabase. http:// courses. washington.edu /geog464/ geodatabase_development.doc. [ 20 April 2011].

Ostländer, N., 2004. Interoperable services for web-based spatial decision support, in: 7th AGILE Conference on Geographic Information Science, Heraklion, Greece, AGILE.

Ray, J.J., 2007. A web-based spatial decision support system optimizes routes for oversize/ overweight vehicles in Delaware. Decis. Support Syst. 43, 1171-1185.

Rinner, C., 2003. Web-based spatial decision support: status and research directions. J. Geogr. Inf. Decis. Anal. 7, 14-31.

Santosa, W. S \& Adji, N. A.. 2007. The Investigation of Ground Water Potential by Vertical Electrical Sounding (VES) Approach in Arguni Bay Region, Kaimana Regency, West Papua. Forum Geografi. Vol. 21(1) Juli 2007.

Sudarmadji. 2006. Perubahan Kualitas Air tanah di Sekitar Sumber Pencemar Akibat Bencana Gempa Bumi. Forum Geografi. Vol 20 (2) Desember 2006: 91-119.

Sugumaran, R., DeGroote, J., 2010. Spatial Decision Support Systems Principles and Practices. CRC Press.

Sugumaran, V., Sugumaran, R., 2007. Web-based Spatial Decision Support Systems (WebSDSS): evolution, architecture, examples and challenges. Commun. Assoc. Inf. Syst. 19, 40. 
Whitten, Jeffrey L. 2007. Systems analysis and design methods.- 7th ed. p.cm. ISBN-13: 978-007-305233-5 (alk. paper), ISBN-IO: 0-07-305233-7 (alk. paper). New York: The McGrawHill. 